\title{
Effect of additive particles on mechanical, thermal, and cell functioning properties of poly(methyl methacrylate) cement
}

This article was published in the following Dove Press journal:

International Journal of Nanomedicine

27 May 2014

Number of times this article has been viewed

\section{Morshed Khandaker' \\ Melville B Vaughan ${ }^{2}$ \\ Tracy L Morris ${ }^{3}$ \\ Jeremiah JWhite' \\ Zhaotong Meng'}

'Department of Engineering and Physics, '2Department of Biology, ${ }^{3}$ Department of Mathematics and Statistics, University of Central

Oklahoma, Edmond, OK, USA
Correspondence: Morshed Khandaker Department of Engineering and Physics, University of Central Oklahoma, 100 N University Drive, Edmond, OK 73034, USA

Tel +l 4059745935

Fax + I 4059743812

Email mkhandaker@uco.edu
Abstract: The most common bone cement material used clinically today for orthopedic surgery is poly(methyl methacrylate) (PMMA). Conventional PMMA bone cement has several mechanical, thermal, and biological disadvantages. To overcome these problems, researchers have investigated combinations of PMMA bone cement and several bioactive particles (micrometers to nanometers in size), such as magnesium oxide, hydroxyapatite, chitosan, barium sulfate, and silica. A study comparing the effect of these individual additives on the mechanical, thermal, and cell functional properties of PMMA would be important to enable selection of suitable additives and design improved PMMA cement for orthopedic applications. Therefore, the goal of this study was to determine the effect of inclusion of magnesium oxide, hydroxyapatite, chitosan, barium sulfate, and silica additives in PMMA on the mechanical, thermal, and cell functional performance of PMMA. American Society for Testing and Materials standard three-point bend flexural and fracture tests were conducted to determine the flexural strength, flexural modulus, and fracture toughness of the different PMMA samples. A custom-made temperature measurement system was used to determine maximum curing temperature and the time needed for each PMMA sample to reach its maximum curing temperature. Osteoblast adhesion and proliferation experiments were performed to determine cell viability using the different PMMA cements. We found that flexural strength and fracture toughness were significantly greater for PMMA specimens that incorporated silica than for the other specimens. All additives prolonged the time taken to reach maximum curing temperature and significantly improved cell adhesion of the PMMA samples. The results of this study could be useful for improving the union of implant-PMMA or bone-PMMA interfaces by incorporating nanoparticles into PMMA cement for orthopedic and orthodontic applications.

Keywords: poly(methyl methacrylate), magnesium oxide, hydroxyapatite, chitosan, barium sulfate, silica, flexural strength, fracture toughness, curing temperature, cell viability

\section{Introduction}

Joint replacement surgery is one of the greatest medical advances of modern medicine. The annual number of hip and knee replacements is now reaching 500,000 in the USA. ${ }^{1}$ Two methods for implanting femoral stems in total hip arthroplasty are available. ${ }^{2}$ First, the femoral stem may be press-fitted into the femoral bone. Second, it may be secured with the femoral bone using bone cement. Metals are the most common femoral stem material. Metals used in femoral stems include titanium, stainless steel, and cobalt chrome. Bone cement is used in joint replacement surgeries. The most common bone cement material used is poly(methyl methacrylate) (PMMA). PMMA cement is associated with several drawbacks that limit its efficacy, such as a strong exothermic reaction, weak radiopacity, and poor mechanical strength compared with the host bone. The most challenging issue 
associated with commercially available PMMA bone cements such as Cobalt ${ }^{\circledR}$ (Biomet Inc., Warsaw, IN, USA), Simplex ${ }^{\text {TM }}$ (Stryker Corporation, Kalamazoo, MI, USA), and Palacos ${ }^{\circledR}$ (Heraeus Holding GmbH, Hanau, Germany) when used in total joint replacement is their poor osseointegration, ie, incorporation of the cement into the surrounding bone tissues. ${ }^{3}$ Polymeric materials are known to have an exothermic reaction during polymerization. This releases heat, and can cause damage to the surrounding bone cells as well as other adjacent tissues. Other reported problems include infection and loosening of the cement at the bonecement interface. ${ }^{4}$ One way to reduce the risk of infection and loosening would be to promote growth of osteoblasts around the cemented surfaces. Such cells would eliminate contact between the bone and the environment and restrict contamination at the cemented prosthetic joint. Another way to reduce loosening would be to increase the mechanical interlocking between bone and cement., 5 This can be done by enhancing the surface roughness of the PMMA cement. Several research groups have reported improvement in the biological, thermal, and mechanical properties of PMMA bone cement after incorporating various types of additive particles (AP) into the cement. Specifically, at least one biological, thermal, or mechanical benefit has been reported due to incorporation of magnesium oxide $(\mathrm{MgO})$, hydroxyapatite (HAp), chitosan (CS), barium sulfate $\left(\mathrm{BaSO}_{4}\right)$, or silica $\left(\mathrm{SiO}_{2}\right)$ with PMMA. ${ }^{7-11}$ Ricker et $\mathrm{al}^{7}$ investigated the influence of nanosized $\mathrm{MgO}$ AP on the thermal, surface, and cytocompatibility properties of PMMA cement. They reported that, compared with PMMA containing microsized $\mathrm{MgO}$, PMMA with nanosized $\mathrm{MgO}$ reduced the harmful exothermic behavior of PMMA during solidification and also increased radiopacity and improved osteoblast function. Serbetci et $\mathrm{al}^{8}$ found that addition of HAp to lowviscosity cement compositions caused an increase in compressive strength and compressive elastic modulus (addition of 7.7\% [weight/weight $\{\mathrm{w} / \mathrm{w}\}$ ] and $14.3 \%$ [w/w] HAp), but caused a decrease in tensile strength. Tunney et $\mathrm{al}^{9}$ found that incorporating CS into gentamicin-loaded Palacos $\mathrm{R}$ bone cement for use in revision surgery had no clinical antimicrobial benefit, and its detrimental effect on mechanical properties could adversely affect the longevity of the prosthetic joint.

Studies reported by Ricker et $\mathrm{al}^{7}$ and Gillani et al ${ }^{10}$ demonstrated that $\mathrm{PMMA}$ containing $\mathrm{BaSO}_{4}$ significantly altered the mechanical properties and osteoblast function associated with PMMA. Hong et al ${ }^{11}$ found improved glass transition temperature, surface hardness, flexural strength, and impact strength for PMMA reinforced by $\mathrm{SiO}_{2}$ nanoparticles compared with PMMA alone.
The above studies suggested that $\mathrm{MgO}, \mathrm{HAp}, \mathrm{CS}, \mathrm{BaSO}_{4}$, and $\mathrm{SiO}_{2}$ confer additional thermal, biological, and mechanical benefits to PMMA. However, we are not aware of a comparative study of the mechanical, thermal, and biological performance of PMMA with respect to that of PMMA bone cement incorporating those AP. Such research would be of interest to those working on the design of novel or improved bone cements for orthopedic applications, such as total hip arthroplasty.

Although the success rates for total hip arthroplasty are now around 97\%, the problems of osteolysis and aseptic loosening have yet to be resolved. ${ }^{12}$ A common cause of cemented joint failure involves loosening at the bone-cement or implant-cement interface. This begins with microfracture at the interface and progresses with cyclical physiological loading, most notably due to mixed mode stresses. Our previous studies found that addition of $\mathrm{MgO}$ nanoparticles to PMMA cement improved the fracture toughness of the bone/PMMA interfaces. ${ }^{13}$ Additionally, our previous studies found that micron diameter polycaprolactone fiber coating on titanium surface improved the fracture toughness of the titanium/PMMA interfaces. ${ }^{14}$ Increased surface roughness, local contact stress, and surface energy are some of the major mechanical factors contributing to the improvements seen with these cemented implants. ${ }^{15-18}$ Increased surface roughness decreases the risk of crack micromovement at the interface, thus increasing load and elongation at the fracture. Cements incorporating microsized or nanosized $\mathrm{MgO}$ particles have a lower elastic modulus and higher exothermic curing temperatures $^{7}$ than those without $\mathrm{MgO}$. Lower modulus cement can diminish local contact stresses at the bonecement interface. ${ }^{19}$ Residual stresses caused by the exothermic temperature difference can influence the fracture energies at the bone-cement interface. ${ }^{15}$ The accumulation of stresses due to differences in modulus and temperature at the interface of bone-cement or implant-cement with AP can be lower than that without AP, resulting in higher interface fracture strength for interfaces with AP than those without AP. Osseointegration is another promising technique for improving cemented implants. ${ }^{20-26}$ Improvement of the implant interface properties to avoid loosing of the implant from the host tissue have been a focus in our research, particularly the improvement of the bonecement and titanium-cement interfaces for the cemented implants. The suitability of using PMMA cement with AP inclusions to solve the loosening problem requires a detailed understanding of its mechanical, thermal, and cell function properties. Therefore, the goal of this study 

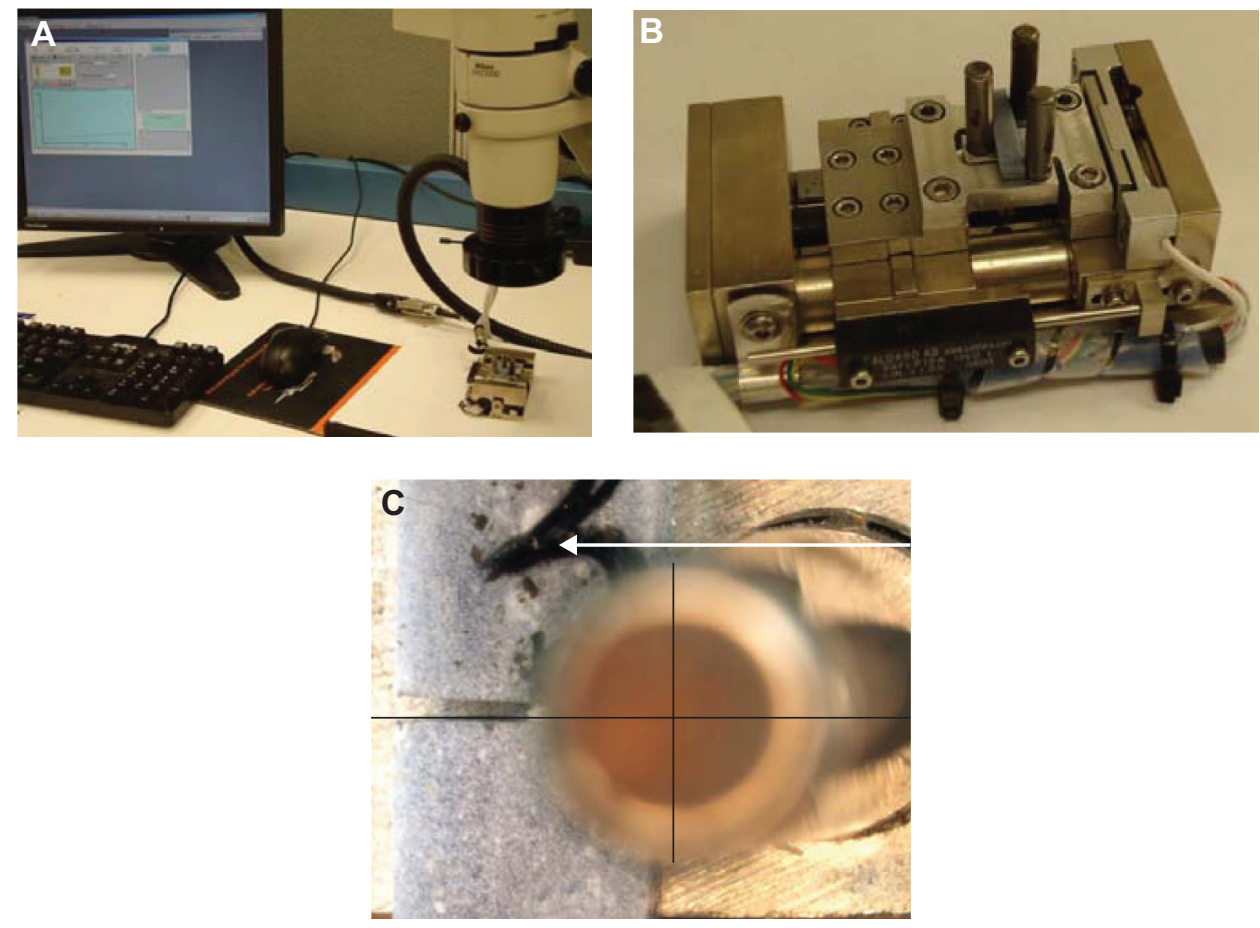

Figure I (A) Evex mechanical test system (Evex Analytical Instruments Inc., Princeton, NJ, USA) used for the three-point flexural and fracture tests in the different PMMA samples. (B) Fabricated indenter and support fixtures for flexural tests. (C) Alignment of a notched specimen during fracture tests. During the tests, two lines perpendicular to each other were drawn to align the center of the notch with the center of the roller on the indenter using a Nikon stereomicroscope and NIS BR software (Nikon, Tokyo, Japan).

Abbreviation: PMMA, poly(methyl methacrylate).

was to identify microsized to nanosized AP that would not only increase surface roughness, attenuate the exothermic reaction, and enhance cell adhesion to PMMA cement, but would also increase the strength of the implant-cement or bone-cement interface. To achieve this goal, we compared the mechanical, thermal, and biological performance of PMMA bone cement samples incorporating AP $(\mathrm{MgO}$, HAp, CS, $\mathrm{BaSO}_{4}$, or $\mathrm{SiO}_{2}$ ).

This study focused on three research questions as follows: whether there is a significant difference in mechanical properties (flexural strength, flexural modulus, and fracture toughness) between PMMA (control) and PMMA-AP cements; whether there is a significant difference in thermal properties (maximum curing temperature and time taken to reach maximum curing temperature) between PMMA and PMMA-AP cements; and whether there is a significant difference in cell function (adhesion and proliferation) between PMMA and PMMA-AP cements.

\section{Materials and methods Materials}

Cobalt HV was used as the PMMA cement. MgO, HAp, $\mathrm{CS}, \mathrm{BaSO}_{4}$, and $\mathrm{SiO}_{2} \mathrm{AP}$ were used as the additives for the PMMA bone cements. All AP were purchased from SigmaAldrich (St Louis, MO, USA).

\section{Sample preparation}

\section{Mechanical tests}

Evex mechanical test system (Evex Analytical Instruments Inc., Princeton, NJ, USA) were used for the three-point flexural and fracture tests on the different PMMA samples (Figure 1A). Following the manufacturer's recommendations, PMMA specimens were prepared by hand mixing $2.2 \mathrm{~g}$ of PMMA powder with $1.1 \mathrm{~mL}$ of methyl methacrylate monomer using a powder to monomer ratio of $2: 1$. Ten wt $\%(0.22 \mathrm{~g})$ of the selected AP were mixed with $1.98 \mathrm{~g}$ of PMMA beads to prepare PMMA with AP-added PMMA cements. The mixers were added with $1.1 \mathrm{~mL}$ of methyl methacrylate monomers maintaining the same powder to monomer ratio of 2:1 for preparation of the respective PMMA-AP samples (PMMA-MgO, PMMA-HAp, PMMA-CS, PMMA$\mathrm{BaSO}_{4}$, and PMMA-SiO${ }_{2}$ ). All samples were cured in a custom-made mold ${ }^{13}$ at $60 \mathrm{kPa}$ (the pressure used during orthopedic surgical procedures $)^{27}$ to a block of size $20 \times 8 \times 10 \mathrm{~mm}$. The pressure was applied at exactly 3 minutes after the start of mixing and was sustained throughout the curing period (approximately 15 minutes). ${ }^{18}$ To prepare American Society for Testing and Materials F417-78 standard flexural test samples (Figure 1B), ${ }^{28} 20 \times 4 \times 2 \mathrm{~mm}$ blocks were cut from the $20 \times 8 \times 10 \mathrm{~mm}$ block using an IsoMet ${ }^{\circledR}$ low-speed cutter (Buehler, Lake Bluff, IL, USA). A $4 \times 0.012 \times 0.5$ inch wafering 
blade was used to cut the samples. To prepare the American Society for Testing and Materials E399-83 single-edge notch bend test samples (Figure 1C), ${ }^{29} 20 \times 4 \times 2 \mathrm{~mm}$ blocks were cut from a $20 \times 8 \times 10 \mathrm{~mm}$ block using the low-speed cutter. To prepare the single-edge notch bend test samples, a center notch was cut at the middle of the $20 \times 4 \times 2 \mathrm{~mm}$ cement samples using the low-speed cutter. A $4 \times 0.012 \times 0.5$ inch wafering blade was used to cut the samples. The samples were stored in an antistatic ziplock bag at room temperature.

\section{Thermal test}

The PMMA samples were prepared as described in the previous section. The mold used for preparing the samples for mechanical testing was also used for the thermal experiments (Figure 2). The only difference was one of the side blocks in the mold used in the thermal experiment had a hole through which a thermocouple was accessed at the center of the curing PMMA cement.

\section{Cell function tests}

Two groups of samples were prepared for cell adhesion and proliferation tests. An acrylic sheet (half an inch thick) was used to create a well for the cell culture (Figure 3). Holes (height $11 \mathrm{~mm}$ and diameter $9.525 \mathrm{~mm}$ ) were milled using a computer numeric control machine. PMMA specimens were prepared by mixing $0.5 \mathrm{~g}$ of PMMA beads with $0.25 \mathrm{~mL}$ of methyl methacrylate. The PMMA-AP specimens were prepared by mixing $0.05 \mathrm{~g}$ of the selected additives with the PMMA beads and dissolving the mixture produced with $0.25 \mathrm{~mL}$ of methyl methacrylate. All PMMA samples, while still pliable, were divided into four parts using a knife and poured on the well. Each part of the samples was hand-pressed during curing by a flat-ended $3 / 8$ inch highly polished round bar. All the wells were wrapped in plastic. Cell adhesion and proliferation test sample wells were kept in a bio-hood under ultraviolet light until cell culture.

\section{Scanning electron and atomic force microscopy}

Scanning electron microscopy (SEM) and atomic force microscopy (AFM) samples of the different PMMA formulations were prepared in the same acrylic wells as discussed in the previous section. A $5 \times 5 \mathrm{~mm}$ coupon was cut out around the center of the well using a low-speed saw cutter to prepare the SEM and AFM samples. All wells were wrapped in plastic and stored at room temperature until analysis.

\section{Experiments}

\section{Particle size analysis}

Particle sizes were measured by the laser diffraction method using a Mastersizer MS3000 (serial number MAL1057538; Malvern Instruments Inc., Westborough, MA, USA). The MS3000 can measure the particle size distribution across a range of 0.01-3,500 $\mu \mathrm{m}$. The samples were analyzed dry using Aero S accessories dry powder disperser (Malvern Instruments Inc., Westborough, MA, USA). Each sample was mixed well by gently turning the container upside down several times. The material was scoop-sampled and placed into the vibratory hopper of the Aero S. Consecutive repeat measurements (each 1 second in duration) were undertaken to assess the reproducibility of measurement, which is a function of the homogeneity of the material. The mass flow was adjusted until a stable and correct particle concentration was achieved at 4 bar and then kept constant for the remainder of the experiments. The maximum diameter of the particle size for 10, 50 and 90 percentage volume for each of the AP, represented by $\mathrm{D}(10)$, $\mathrm{D}(50)$, and $\mathrm{D}(90)$, were extracted from the MS3000 report.
A

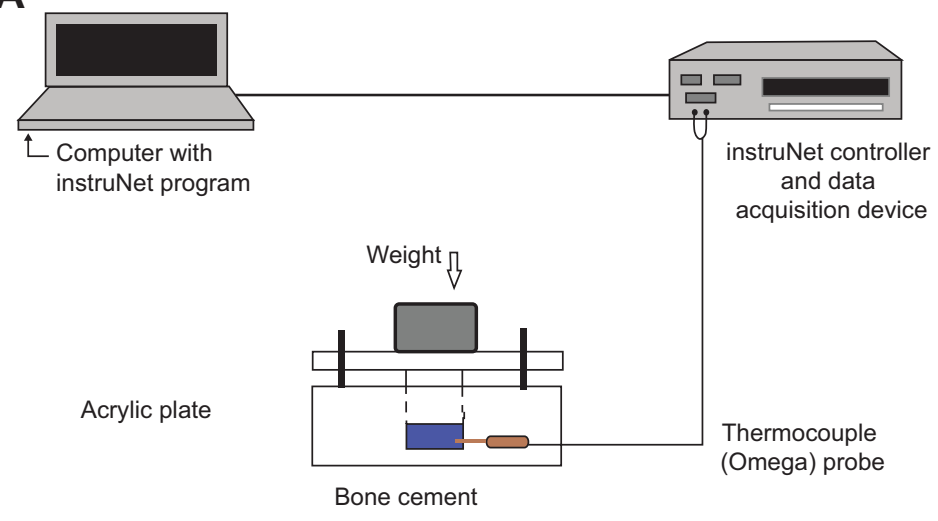

B

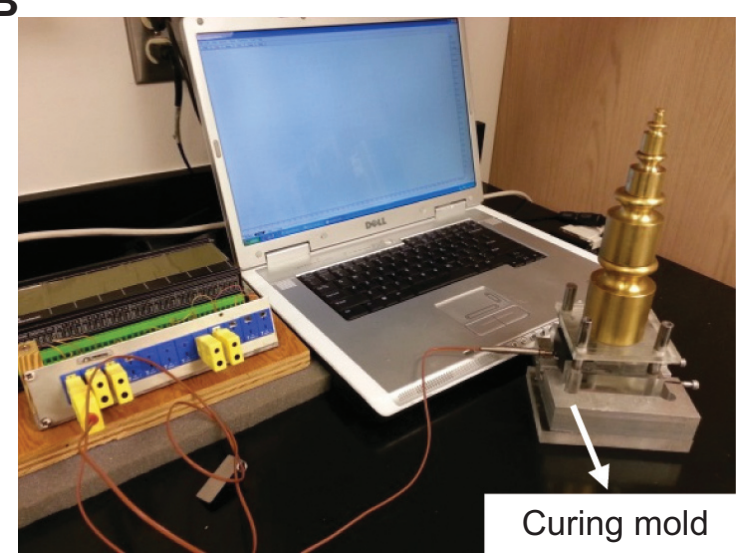

Figure 2 (A) Schematic view of the experimental setup for measurement of exothermic temperature of PMMA cement. (B) Fabricated setup for measurement of exothermic temperature of PMMA cement.

Note: InstruNet: Omega Engineering, Inc., Stamford, CT, USA.

Abbreviation: PMMA, poly(methyl methacrylate). 
$\mathbf{A}$

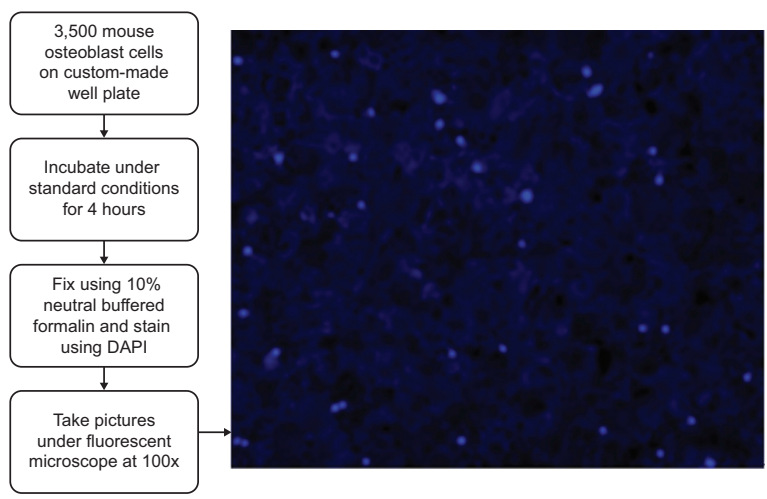

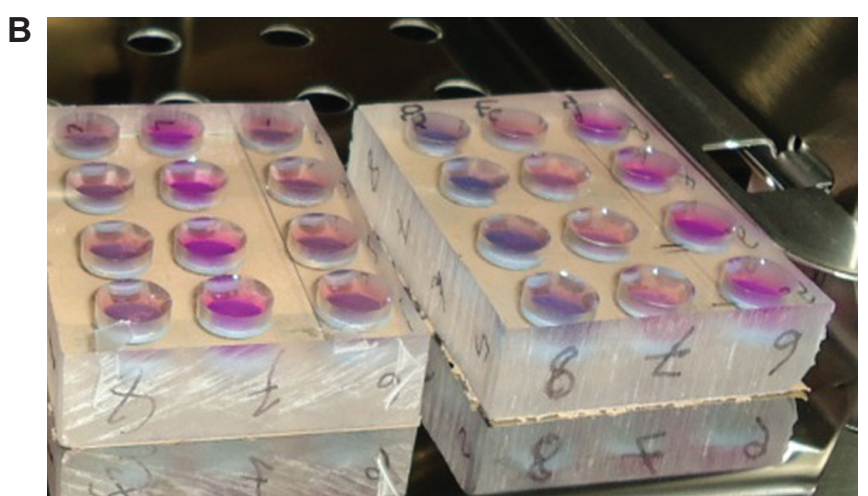

Figure 3 Cell culture protocols for cell adhesion tests on PMMA, including (A) a DAPI-stained image showing osteocyte nuclei and (B) a custom-made well plate for culturing cells on PMMA cements.

Abbreviations: DAPI, 4',6-diamidino-2-phenylindole; PMMA, poly(methyl methacrylate).

\section{Mechanical tests}

The three-point bend tests on the rectangular and notched samples were conducted at room temperature and at a loading rate of $0.01 \mathrm{~mm} / \mathrm{sec}$ using a tensile stage (Evex Analytical Instruments Inc., Princeton, NJ, USA) as shown in Figure 1A. The stage was assembled with a $300 \mathrm{~N}$ load cell. The specimens were mounted on the custom-made three-point bend indenter and support in the test stage during the flexural tests (Figure 1B). During the single-edge notch bend test, an SMZ1000 stereomicroscope with a DS-Fi-1 camera and $\mathrm{U} 2$ controller (Nikon, Tokyo, Japan) was used to align the notch center of the specimen and the center of the indenter round edge. Figure $1 \mathrm{C}$ shows the alignment of the single-edge notch bend specimen center with the center of the three-point bend indenter on the Evex test stage. Nikon NIS BR visualization software was used for the alignment. Load and displacement were continuously recorded using Evex nanoanalysis software until failure of the specimens. Several mechanical performance parameters were derived from the three-point bend flexural test for the various PMMA specimens. Stress and strain were calculated from load and displacement data using:

$$
\sigma=3 P S / 2 B W^{2}
$$

and

$$
\varepsilon=6 d W / S^{2}
$$

respectively, where $P$ is the incremental load, $d$ is the incremental deflection, $S$ is the standard loading span for the three-point bend specimen, $B$ is the thickness, and $W$ is the width of the specimen. Flexural strength, $\sigma_{\mathrm{f}}$, was calculated using: ${ }^{30}$

$$
\sigma_{\mathrm{f}}=3 P_{\max } S / 2 B W^{2}
$$

where $P_{\max }$ is the ultimate load (force at failure). The value of the bending modulus, $E$, for a three-point bend specimen was measured from the slope of the stress-strain curve at the elastic region. From the single-edge notch bend test, the maximum load, $P_{\text {max }}$, at the onset of crack extension from the notch tip was recorded from load displacement data. $P_{\text {max }}$ was used to calculate the mode I fracture toughness, $K_{\text {IC }}$ using the relationship: ${ }^{31}$

$$
K_{\mathrm{IC}}=P_{\max } S f(\alpha) / B W^{3 / 2}
$$

where $S$ is the span length (ie, the length between two support rollers), $\alpha$ is the normalized initial crack length $(\alpha=a / W)$, and $f(\alpha)$ is a dimensionless geometric function. The following equation was used to calculate $f(\alpha):{ }^{31}$

$$
f(\alpha)=\frac{3(\alpha)^{1 / 2}\left[1.99-(\alpha)(1-\alpha) \times\left(2.15-3.93 \alpha+2.7(\alpha)^{2}\right)\right]}{2(1+2(\alpha))(1-\alpha)^{3 / 2}}
$$

\section{Thermal tests}

A custom-made temperature measurement system (Figure 2A and $2 \mathrm{~B}$ ) was used to determine the temperature changes for the different PMMA cements in an insulated acrylic mold. A four-channel DI-1000-TC thermocouple (DATAQ Instruments, Akron, OH, USA) was used to measure the temperature changes in the bone cements. The thermocouple was connected to a data acquisition device that was in turn connected to a computer utilizing InstruNet software for data collection. The PMMA sample was placed on the acrylic mold. The thermocouple needle was inserted up to the center of the sample through the side block hole. The sample was pressed from above by a set of weights equivalent to $60 \mathrm{kPa}$ pressure. The temperature change was recorded by the 
thermocouple needle every 25 seconds for 30 minutes until the PMMA sample was completely solidified.

\section{Cell adhesion tests}

Osteoblast adhesion to the PMMA and PMMA-AP samples was investigated using mouse osteoblasts (MT3T3E1; American Type Culture Collection, Manassas, VA, USA). The cells were cultured according to American Type Culture Collection instructions using a cell viability test protocol as depicted in Figure 3A. Cells were seeded at a density of 3,500 cells $/ \mathrm{mL}$ in each well and incubated under standard conditions (a humidified, $5 \% \mathrm{CO}_{2}$, and $95 \%$ air environment at $37^{\circ} \mathrm{C}$ ) for 4 hours. Cells were fixed in $10 \%$ neutral buffered formalin and stained using 4',6-diamidino-2-phenylindole, a DNA-binding fluorescent probe. Cells were counted in five fields per substrate and images were captured with a BX41 fluorescent microscope (Olympus, Tokyo, Japan) at $100 \times$ total magnification. Cell numbers were counted using Nikon BR image processing software.

\section{Cell proliferation tests}

For the proliferation tests, the cells were cultured for an hour according to the same method described in the previous section. Proliferation was analyzed using a Click-iT kit (Invitrogen, Thermo Fisher Scientific, Waltham, MA, USA). Briefly, samples were incubated for 1 hour in the presence of ethynyl-deoxyuridine, a modified nucleotide that is incorporated into cells, replicating their DNA during the proliferation process. Samples were fixed for 5 minutes in ice-cold methanol and incubated for 30 minutes with an Click-iT ${ }^{\circledR}$ EdU Alexa-488 (Molecular Probes, Eugene, OR, USA). fluorescent tag to label the ethynyl-deoxyuridine nucleotides. After washing in phosphate-buffered saline, the samples were mounted with $80 \%$ glycerol/phosphatebuffered saline containing 4',6-diamidino-2-phenylindole to counterstain all nuclei blue.

\section{Scanning electron microscopy}

Using a Quanta 600 field-emission gun environmental SEM with an Evex X-ray energy dispersive spectroscopy microanalysis system (FEI; Thermo Fisher Scientific), the PMMA samples prepared to characterize AP dispersion and surface topography. The prepared SEM samples were sputter-coated with gold and palladium for 1 minute.

\section{Atomic force microscopy}

Using a multimode scanning probe microscope with an AFM module (Veeco, Santa Clara, CA, USA), the PMMA samples prepared to provide quantitative evidence of the difference in surface roughness for different PMMA samples. The prepared SEM samples were sputter-coated with gold and palladium for 1 minute. All roughness values $\left(\mathrm{R}_{\mathrm{q}}, \mathrm{R}_{\mathrm{m}}, \mathrm{R}_{\max }\right)$ were measured in three areas on each substrate using installed software (Nanoscope 4.42, Veeco).

\section{Statistical analysis}

Data collated for all experimental tests were evaluated for statistical significance using one-way analysis of variance with subsampling. To determine specifically which means were significantly different, multiple comparisons were performed using Fisher's protected least significant difference. All the tests were conducted using SAS version 9.1 (SAS Institute, Cary, NC, USA). For all analyses, statistical significance was considered as $P<0.05$.

\section{Results \\ Particle size}

Table 1 shows the particle size distribution of the $\mathrm{MgO}$, HAp, $\mathrm{CS}, \mathrm{BaSO}_{4}$, and $\mathrm{SiO}_{2}$ powders obtained by laser diffraction. The average particle sizes of the AP were mainly micrometer in scale. The average particle size of $\mathrm{MgO}$ was lowest and CS was highest when compared with the other AP particles.

\section{Mechanical tests}

The stress-strain behavior of PMMA was influenced by incorporation of AP (Figure 4A). The flexural strength $\left(\sigma_{\mathrm{f}}\right)$ and flexural modulus $(E)$ under bending loading conditions was calculated from the stress-strain data for all the bone cements (Table 2). These data, along with the bar diagram (Figure 4B), were used to identify significant differences in flexural strength when comparing the control cement (PMMA) with the cements containing AP. Figure 4B shows that: the mean $\sigma_{\mathrm{f}}$ of the $\mathrm{SiO}_{2}$ specimens was significantly greater than the mean $\sigma_{\mathrm{f}}$ of all other specimens; the mean $\sigma_{\mathrm{f}}$ of the PMMA-BaSO ${ }_{4}$ specimens was significantly greater than the mean $\sigma_{\mathrm{f}}$ of the PMMA-MgO specimens; and no significant difference existed between the mean $\sigma_{\mathrm{f}}$ of the PMMA control,

Table I Particle size parameters of the additive powders used in the study

\begin{tabular}{llll}
\hline Types & $D(10)^{\mathrm{a}}(\mu \mathrm{m})$ & $D(50)(\mu \mathrm{m})$ & $D(90)^{\mathrm{b}}(\mu \mathrm{m})$ \\
\hline $\mathrm{MgO}$ & 0.05 & 0.38 & $0.6 \mathrm{I}$ \\
$\mathrm{HAp}$ & 0.56 & 1.17 & 35.5 \\
Chitosan & 125 & 454 & 1,000 \\
$\mathrm{BaSO}_{4}$ & 0.7 & 1.7 & 3.38 \\
$\mathrm{SiO}_{2}$ & 6.84 & 15.4 & 30.3 \\
\hline
\end{tabular}

Notes: ${ }^{a} D(10)$ indicates that $10 \%$ of the powder particles are smaller than this value; ${ }^{b} D(90)$ indicates that $90 \%$ of the powder particles are smaller than this value.

Abbreviations: CS, chitosan; D, diameter; $\mathrm{HAp}$, hydroxyapatite; $\mathrm{MgO}$, magnesium oxide; $\mathrm{PMMA}$, poly (methyl methacrylate); $\mathrm{BaSO}_{4}$, barium sulfate; $\mathrm{SiO}_{2}$, silica. 
A

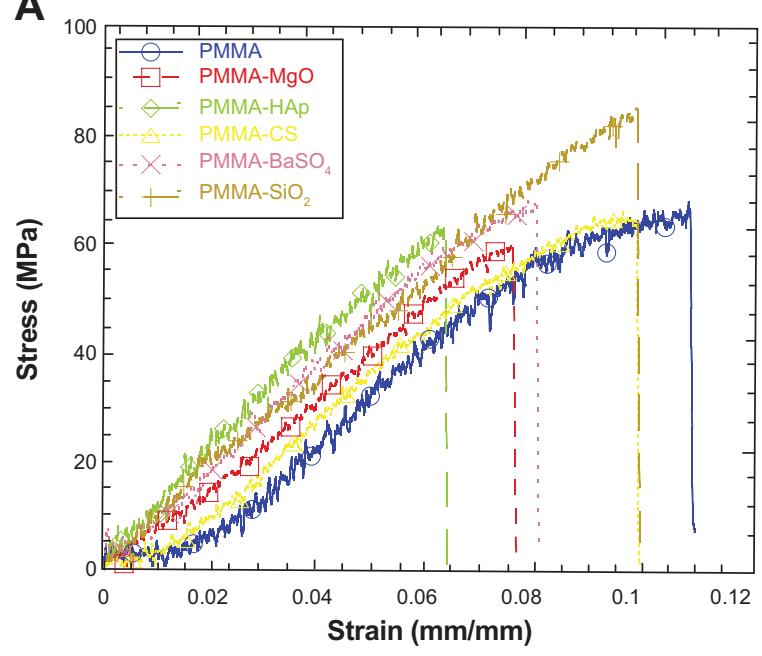

B

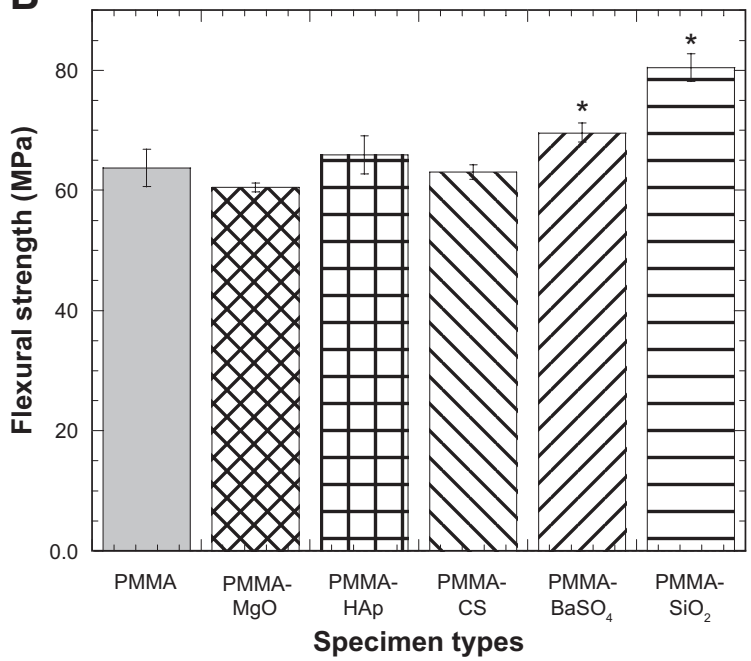

Figure 4 (A) Stress versus strain plots of PMMA samples tested during this study. (B) Bar diagram of the variation in flexural strength of PMMA samples due to variation of additives to PMMA.

Notes: Data are presented as the mean \pm standard error of mean; $n=3$ for PMMA-CS; $n=4$ for the rest of the samples. $* P<0.05$ (compared with PMMA).

Abbreviations: CS, chitosan; $\mathrm{HAp}$, hydroxyapatite; $\mathrm{MgO}$, magnesium oxide; $\mathrm{PMMA}$, poly(methyl methacrylate); $\mathrm{BaSO}_{4}$, barium sulfate; $\mathrm{SiO}_{2}$, silica.

PMMA-CS, and PMMA-HAp. Table 2 shows the differences of the values of $E$ of additives included in the PMMA samples with respect to the values of $E$ of PMMA. The results show that: the mean $E$ of the $\mathrm{SiO}_{2}$ specimens was significantly greater than the mean $E$ of all other specimens; the mean $E$ of the PMMA and PMMA-BaSO ${ }_{4}$ specimens was significantly greater than the mean modulus of the PMMA-MgO specimens; and no significant difference existed between the mean $E$ of PMMA-CS and PMMA-HAp. Figure 5 compares the fracture toughness of various composite cements with respect to the fracture toughness of PMMA. Results show that incorporation of HAp, CS, and $\mathrm{SiO}_{2} \mathrm{AP}$ with PMMA significantly influences the fracture toughness of the PMMA. Furthermore, Table 2 shows that the mean values of the fracture toughness of all AP incorporated PMMA samples were higher than the mean values of the fracture toughness of PMMA samples.

\section{Thermal tests}

Figure 6 shows the variation in curing temperature with respect to time for the different PMMA samples. All samples showed the similar characteristic of temperature increase to a peak temperature $\left(T_{\mathrm{c}}\right)$ and a temperature decrease after $T_{\mathrm{c}}$. It is also evident from the graph that the AP influenced the time taken to reach $T_{\mathrm{c}}$, which was lowest for the PMMA samples without additives when compared with PMMA samples including additives. The PMMA cement incorporating $\mathrm{SiO}_{2}$ took the longest to reach maximum temperature. Given that thermal stress is proportional to rise in temperature, the thermal stress created in the PMMA samples must be higher than in the PMMA-AP samples. Table 3 shows the curing temperature of the different samples at intervals of $0,2.5,5,7.5,10,12.5$, and 15 minutes. Table 3 also shows the maximum $T_{\mathrm{c}}$ and time taken to reach $T_{\mathrm{c}}$. MgO-containing, CS-containing, and $\mathrm{BaSO}_{4}$-containing PMMA cements showed a lower maximum temperature than PMMA samples, whereas the HAp-containing and $\mathrm{SiO}_{2}$-containing PMMA cements showed higher maximum temperatures than the PMMA samples.

\section{Cell adhesion tests}

Figure 7A shows the mean osteoblast density for the different PMMA sample types. The bar diagram in Figure 7B demonstrates how the AP affected cell viability in the PMMA

Table 2 Mechanical properties of the different cements

\begin{tabular}{lllllll}
\hline Mechanical properties & PMMA & PMMA-MgO & PMMA-HAp & PMMA-CS & PMMA-BaSO $_{4}$ & PMMA-SiO $_{2}$ \\
\hline Flexural strength (MPa) & $63.74 \pm 5.36$ & $60.52 \pm 1.31$ & $65.93 \pm 5.54$ & $63.06 \pm 2.42$ & $69.60 \pm 2.74$ & $80.44 \pm 3.97$ \\
& $(n=4)$ & $(n=4)$ & $(n=4)$ & $(n=3)$ & $(n=4)$ & $(n=4)$ \\
Bending modulus (MPa) & $895.5 \pm 91.89$ & $947.5 \pm 59.09$ & $946 \pm 86.31$ & $895.00 \pm 31.61$ & $1,020.25 \pm 57.21$ & $1,079.50 \pm 55.34$ \\
& $(n=4)$ & $(n=4)$ & $(n=4)$ & $(n=3)$ & $(n=4)$ & $(n=3)$ \\
Fracture toughness (MPa.m $\left.{ }^{1 / 2}\right)$ & $1.17 \pm 0.17$ & $1.22 \pm 0.05$ & $1.46 \pm 0.10$ & $1.44 \pm 0.08$ & $1.38 \pm 0.27$ & $1.47 \pm 0.13$ \\
& $(n=3)$ & $(n=3)$ & $(n=4)$ & $(n=3)$ & $(n=3)$ & $(n=4)$ \\
\hline
\end{tabular}

Notes: Data in the table are represented in the following sequence: mean \pm standard deviation (number of samples tested).

Abbreviations: $\mathrm{CS}$, chitosan; $\mathrm{HAp}$, hydroxyapatite; $\mathrm{MgO}$, magnesium oxide; $\mathrm{PMMA}$, poly(methyl methacrylate); $\mathrm{BaSO}_{4}$, barium sulfate; $\mathrm{SiO}_{2}$, silica. 


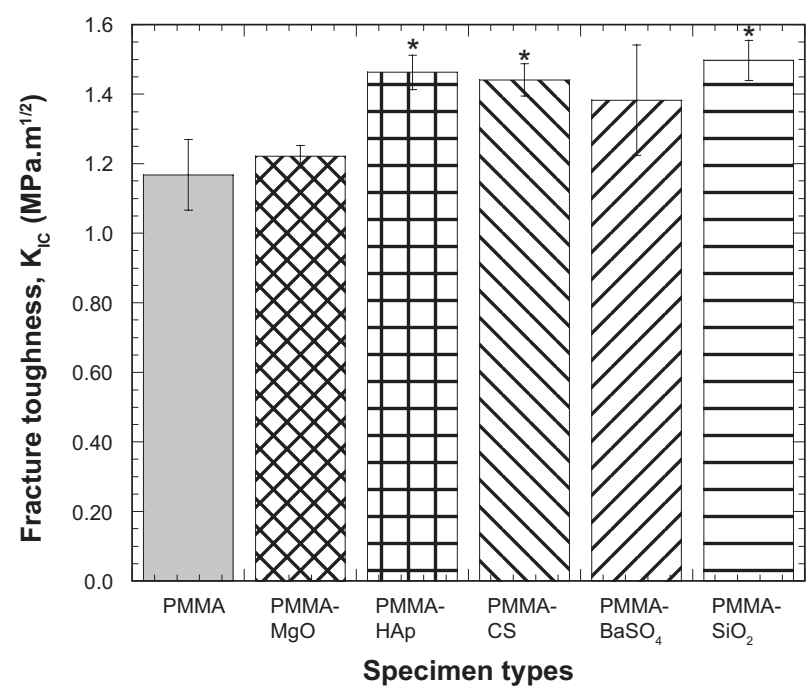

Figure 5 Bar diagram of the variation in fracture toughness of PMMA samples due to variation in additives to PMMA.

Notes: Data are presented as the mean \pm standard error of the mean; $n=4$ for PMMA-HAp and PMMA-SiO ${ }_{2} ; \mathrm{n}=3$ for the rest of the samples. $* P, 0.05$ (compared with PMMA).

Abbreviations: $\mathrm{CS}$, chitosan; HAp, hydroxyapatite; $\mathrm{MgO}$, magnesium oxide; PMMA, poly(methyl methacrylate); $\mathrm{BaSO}_{4}$, barium sulfate; $\mathrm{SiO}_{2}$, silica.

samples. The cell density of the PMMA specimens when additives were included was significantly greater than the cell density of PMMA alone, suggesting that $\mathrm{MgO}$, HAp, CS, $\mathrm{BaSO}_{4}$, and $\mathrm{SiO}_{2}$ have a positive influence on cell activity in PMMA.

\section{Cell proliferation tests}

No proliferation in the cement samples was found, except for a few cells (Figure 8). However, there were many instances of paired cells being found close together, suggesting cell division had occurred. It would have been better to run at least a 24 -hour proliferation assay to confirm that some of the cells were dividing. Proliferation tests were conducted for an hour since the osteoblasts on a coverslip showed a good degree of proliferation (about 50\%) after an hour. These results suggest that it may take longer for cells to become accustomed to the bone matrix material than for cells to acclimate to coverslips.

\section{SEM and AFM analysis}

Qualitative and quantitative examination of SEM and AFM images and data for the different PMMA cements show that the pure PMMA and PMMA-CS samples were less rough than the PMMA samples incorporating other AP (Figures 9 and 10, Table 4).

\section{Discussion}

$\mathrm{MgO}$ is an inorganic white hygroscopic solid mineral that occurs naturally as periclase and is a source of magnesium. This study found that $\mathrm{MgO}$ nanoparticles significantly reduced the flexural strength of PMMA (Figure 4). PMMA$\mathrm{MgO}$ samples had the lowest flexural strength when compared with the other PMMA-AP cements. No significant change in fracture toughness values was found for PMMA$\mathrm{MgO}$ samples when compared with PMMA and PMMA$\mathrm{BaSO}_{4}$. PMMA-MgO samples had lower $K_{\mathrm{IC}}$ values than the other PMMA-AP cements. MgO nanoparticles improved the thermal performance of the PMMA samples by reducing the maximum curing temperature $\left(T_{\max }\right)$ of PMMA, although the $T_{\max }$ for the PMMA-MgO samples was lower than for the other PMMA-AP cements (Figure 5 and Table 3). The time taken for the PMMA-MgO samples to reach $T_{\max }$ was longer than for the other PMMA-AP cements, except PMMA-SiO ${ }_{2}$. No negative cell viability effect on PMMA due to addition of $\mathrm{MgO}$ was observed (Figure 6). These results suggest that the detrimental effect of addition of $\mathrm{MgO}$ nanoparticle additives on the mechanical properties of PMMA bone cement could offset the thermal and biological benefits achieved by inclusion of $\mathrm{MgO}$. The results of our thermal and cell viability studies are in agreement with those of Ricker et al ${ }^{7}$ who also found less harmful exothermic reactions of PMMA during solidification, and increased osteoblast adhesion on PMMA incorporating $\mathrm{MgO}$ nanoparticles, compared with PMMA alone. To our knowledge, no studies have attempted to determine the flexural and fracture properties of $\mathrm{MgO}$-containing PMMA cements.

Table 3 Descriptive statistics of the curing experiment data for PMMA samples

\begin{tabular}{|c|c|c|c|c|c|c|c|c|c|}
\hline \multirow[t]{2}{*}{ Sample type } & \multicolumn{7}{|c|}{ Time (minutes) } & \multirow{2}{*}{$\begin{array}{l}\text { Maximum } \\
\text { temperature } \\
\left({ }^{\circ} \mathrm{C}\right)\end{array}$} & \multirow{2}{*}{$\begin{array}{l}\text { Time to reach } \\
\text { maximum temperature } \\
\text { (minutes) }\end{array}$} \\
\hline & 0 & 2.5 & 5 & 7.5 & 10 & 12.5 & 15 & & \\
\hline PMMA (sample \# I) & 28.97 & 29.41 & 30.34 & 32.23 & 54.50 & & & 54.50 & 10.00 \\
\hline PMMA (sample \# 2) & 28.97 & $29.4 I$ & 30.34 & 32.23 & 54.50 & & & 54.50 & 10.00 \\
\hline PMMA-MgO & 29.50 & 29.95 & 30.17 & 30.72 & 32.09 & 38.95 & 51.08 & 51.08 & 14.17 \\
\hline PMMA-HAP & 29.96 & 31.17 & 31.91 & 33.07 & 40.83 & 59.97 & & 63.70 & 12.08 \\
\hline PMMA-CS & 28.94 & 29.16 & 30.03 & 31.60 & 38.17 & 51.32 & & 51.73 & 12.08 \\
\hline $\mathrm{PMMA}-\mathrm{BaSO}_{4}$ & 28.69 & 29.45 & 29.99 & 30.66 & 33.17 & 50.81 & & 50.81 & 12.50 \\
\hline $\mathrm{PMMA} \mathrm{SiO}_{2}$ & 28.63 & 29.17 & 29.43 & 29.73 & 30.01 & 30.45 & 30.97 & 56.25 & 25.00 \\
\hline
\end{tabular}

Abbreviations: $\mathrm{CS}$, chitosan; $\mathrm{HAp}$, hydroxyapatite; $\mathrm{MgO}$, magnesium oxide; $\mathrm{PMMA}$, poly(methyl methacrylate); $\mathrm{BaSO}_{4}$, barium sulfate; $\mathrm{SiO}_{2}$, silica. 


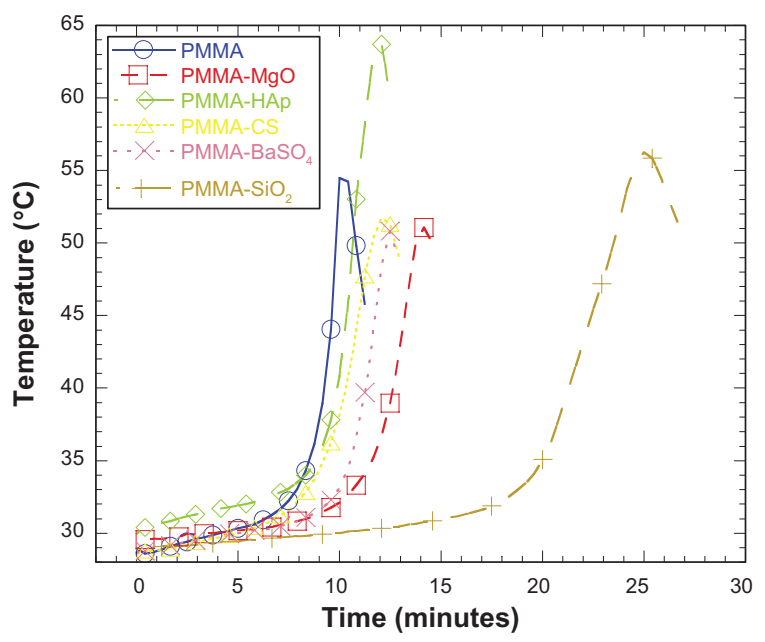

Figure 6 Time versus temperature graphs of different PMMA sample specimens. Abbreviations: $\mathrm{CS}$, chitosan; $\mathrm{HAp}$, hydroxyapatite; $\mathrm{MgO}$, magnesium oxide; PMMA, poly(methyl methacrylate); $\mathrm{BaSO}_{4}$, barium sulfate; $\mathrm{SiO}_{2}$, silica.

HAp is a predominantly crystalline inorganic compound, although it may exist in amorphous forms. ${ }^{32}$ In our study, HAp particles did not affect the flexural strength of PMMA (Figure 4). However, the PMMA-HAp samples had a higher $\sigma_{\mathrm{f}}$ compared with the PMMA-MgO cement and a lower $\sigma_{\mathrm{f}}$ compared with $\mathrm{PMMA}-\mathrm{SiO}_{2}$ cement, but showed no difference in $\sigma_{\mathrm{f}}$ when compared with the other PMMA-AP samples. A significantly higher $K_{\mathrm{IC}}$ value was found for PMMA-HAp samples than for control PMMA and PMMA-MgO samples, but no difference in $K_{\text {IC }}$ was found between PMMA-HAp and other PMMA-AP samples. HAp had a negative effect on the thermal performance of PMMA samples by increasing the maximum curing temperature of PMMA. Additionally, PMMA-HAp

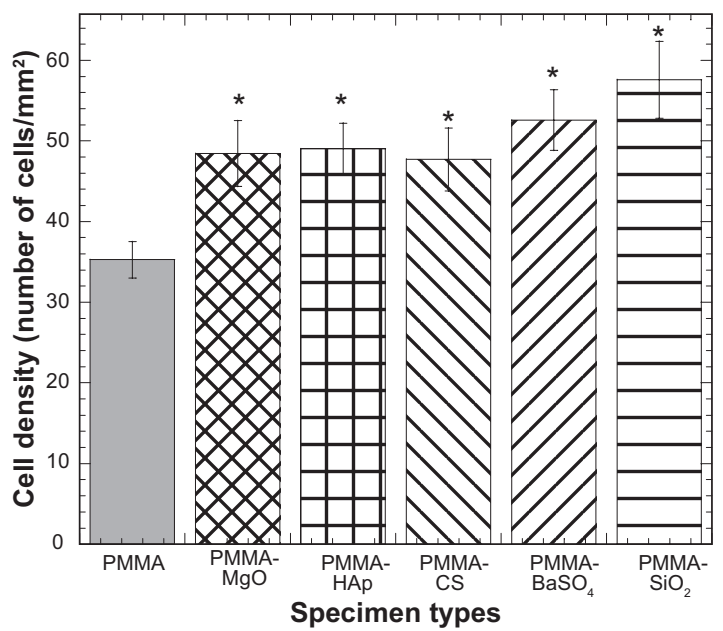

Figure 7 Bar diagram of the variation in cell density with PMMA samples due to variation in additives to PMMA.

Notes: Data are presented as the mean \pm standard error of the mean; $n=8$. $* P<0.05$ versus PMMA.

Abbreviations: $\mathrm{CS}$, chitosan; $\mathrm{HAp}$, hydroxyapatite; $\mathrm{MgO}$, magnesium oxide; $\mathrm{PMMA}$ poly(methyl methacrylate); $\mathrm{BaSO}_{4}$, barium sulfate; $\mathrm{SiO}_{2}$, silica. samples showed the highest $T_{\max }$ when compared with other PMMA-AP cements (Figure 5 and Table 3). The time taken for PMMA-HAp to reach $T_{\text {max }}$ was found to be higher than for PMMA cements lacking additives, lower than for PMMA-MgO and PMMA- $\mathrm{SiO}_{2}$ cements, and not different to that for PMMA-CS and PMMA- $\mathrm{BaSO}_{4}$ cements. We found no negative cell viability effect on PMMA due to addition of HAp (Figure 6).

The above results suggest that a detrimental curing temperature effect could override the mechanical and biological benefits achieved by inclusion of HAp in PMMA. The results of our mechanical and thermal studies are in agreement with those of $\mathrm{Chu}$ et $\mathrm{al}^{33}$ who found inclusion of 10\%-20\% HAp had significant beneficial effects on the mechanical properties of PMMA and that more than $40 \%$ HAp should be mixed into PMMA to reduce the peak curing temperature. However, the results of our thermal studies are not in agreement with those of Serbetci et al ${ }^{8}$ who reported a decrease in peak curing temperature when HAp was added to PMMA. This difference is likely due to the different experimental conditions affecting heat dissipation. Our study modified the experimental conditions used by Serbetci et al to include the use of an insulating mold to minimize heat dissipation during the curing process.

CS is a natural polymer with coagulation and flocculation properties that can be used to treat organic or inorganic particulate suspensions and also to treat dissolved organic materials (including dyes and humic acid). ${ }^{34}$ Like HAp particles, CS particles did not affect the flexural strength of PMMA in our study (Figure 4). PMMA-CS samples also had a higher $\sigma_{\mathrm{f}}$ than the PMMA-MgO cement and a lower $\sigma_{\mathrm{f}}$ than the PMMA-SiO${ }_{2}$ cement, with no difference in $\sigma_{\mathrm{f}}$ when compared with the other PMMA-AP samples. A significantly higher $K_{\text {IC }}$ value was found for PMMA-CS samples than for PMMA and PMMA-MgO, with no difference in $K_{\mathrm{IC}}$ for PMMA-CS when compared with the rest of the PMMA-AP samples. In contrast with HAp, CS had a positive effect on the thermal performance of the PMMA samples by decreasing the maximum curing temperature of PMMA. $T_{\max }$ for the PMMA-CS samples was lower than for the PMMA only, PMMA-HAp, and PMMA-SiO ${ }_{2}$ samples and similar to the $T_{\max }$ of the remaining PMMA-AP samples (Figure 5 and Table 3). Further, PMMA-CS reached $T_{\max }$ at a lower temperature than the other PMMA-AP samples. Our study found no negative cell viability effects on PMMA when CS was added (Figure 6). These results suggest that CS is one of the most suitable additives for PMMA cement based on the mechanical, thermal, and biological benefits achieved. The results of our flexural 

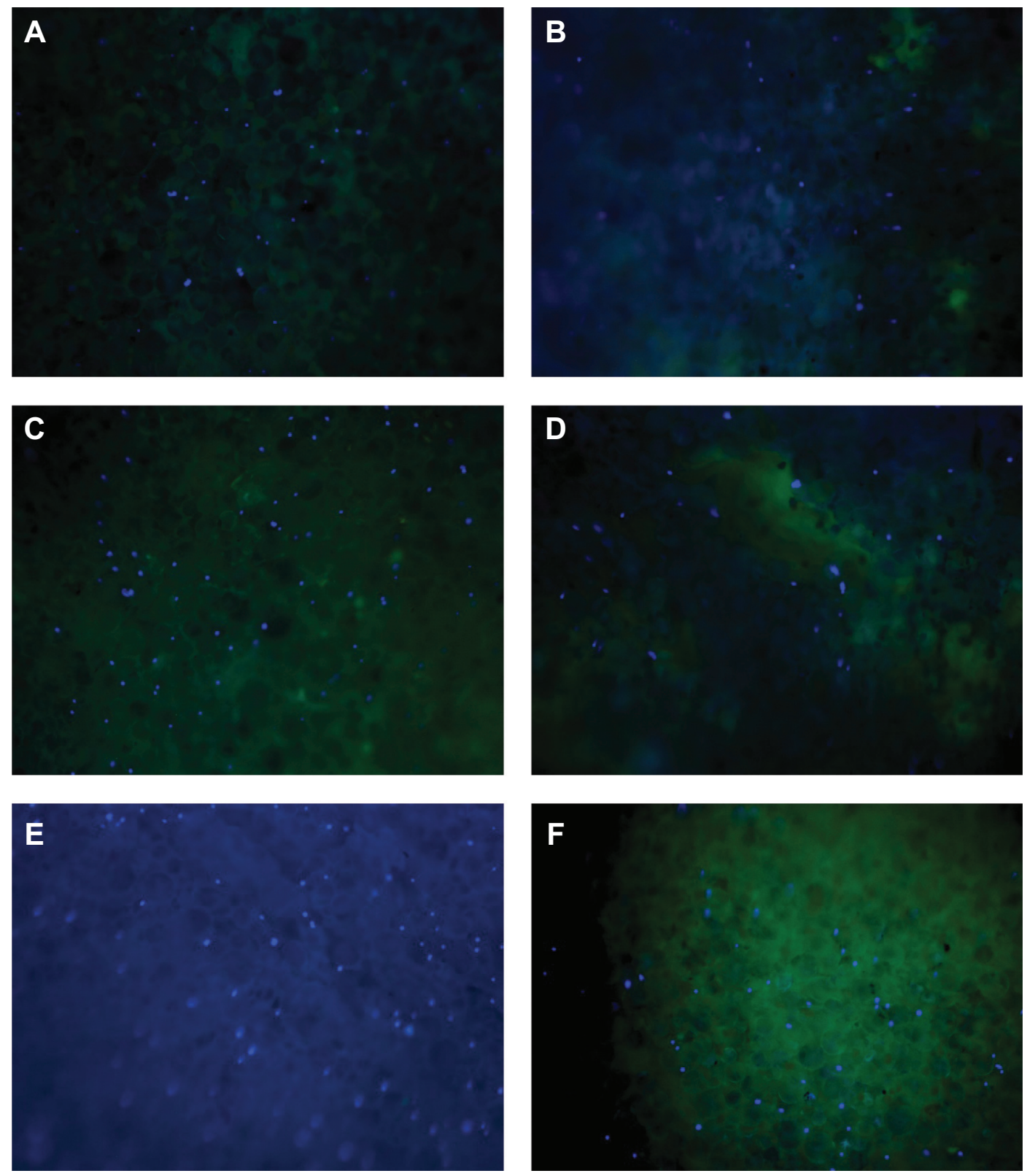

Figure 8 Fluorescent microscope images of different kinds of bone cements used during cell proliferation tests. (A) PMMA, (B) PMMA with MgO, (C) PMMA with HAp, (D) PMMA with CS, (E) PMMA with $\mathrm{BaSO}_{4}$, and (F) PMMA with $\mathrm{SiO}_{2}$.

Abbreviations: $\mathrm{CS}$, chitosan; $\mathrm{HAp}$, hydroxyapatite; $\mathrm{MgO}$, magnesium oxide; $\mathrm{PMMA}$, poly (methyl methacrylate); $\mathrm{BaSO}_{4}$, barium sulfate; $\mathrm{SiO}_{2}$, silica.

tests are in agreement with those of Tunney et $\mathrm{al}^{9}$ who also reported finding no significant difference in flexural strength between PMMA and PMMA containing CS. To our knowledge, no studies have attempted to determine the fracture and curing properties of PMMA cements that include CS.

$\mathrm{BaSO}_{4}$ is an inorganic compound with a white opaque appearance and is used as a radiopacifying agent. We found that the modes of fracture for both PMMA cements and PMMA cement containing $\mathrm{BaSO}_{4}$ ceramic microparticles were brittle. The same phenomena was also observed by Gillani et al. ${ }^{10}$ In contrast, the values for fracture strength and Young modulus of PMMA and PMMA containing $\mathrm{BaSO}_{4}$ reported by Gillani et al ${ }^{10}$ were four to five times lower than those values found in our study. This difference is due to the difference of the mechanical tests to find those values: tension tests were conducted, whereas bending tests were conducted during our study. Young modulus under the tensile loading of PMMA and PMMA containing $\mathrm{BaSO}_{4}$ reported by Gillani et $a{ }^{10}$ were $4-5$ times lower than those values under the bend loading in this study. Like HAp and CS particles, $\mathrm{BaSO}_{4}$ particles did not affect the flexural strength of PMMA (Figure 4). Moreover, ${\mathrm{PMMA}-\mathrm{BaSO}_{4}}_{4}$ samples had a higher $\sigma_{\mathrm{f}}$ than the other PMMA-AP samples, except for PMMA-SiO . 

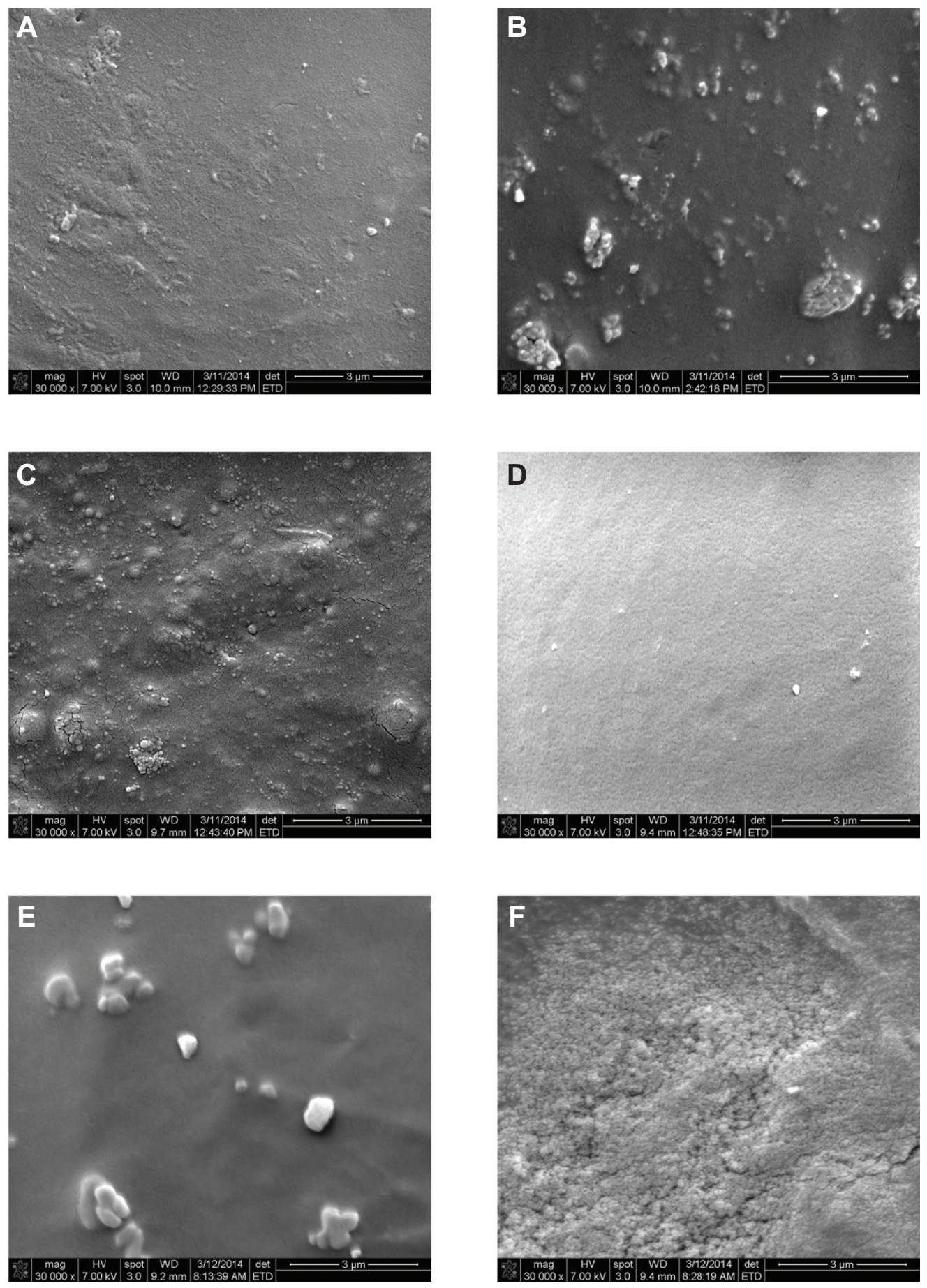

Figure 9 Scanning electron micrographs of the different types of bone cement used in cell function tests $(30,000 \times$, scale bar $3 \mu \mathrm{m})$. (A) PMMA, (B) PMMA with MgO, (C) PMMA with $\mathrm{HAp}$, (D) PMMA with CS, (E) $\mathrm{PMMA}$ with $\mathrm{BaSO}_{4}$, and (F) $\mathrm{PMMA}$ with $\mathrm{SiO}_{2}$.

Abbreviations: $\mathrm{CS}$, chitosan; $\mathrm{HAp}$, hydroxyapatite; $\mathrm{MgO}$, magnesium oxide; $\mathrm{PMMA}$, poly(methyl methacrylate); $\mathrm{BaSO}_{4}$, barium sulfate; $\mathrm{SiO}_{2}$, silica.

The $K_{\mathrm{IC}}$ values of the PMMA-CS samples were not significantly different from that of PMMA or the other PMMA-AP samples. Like $\mathrm{MgO}$ and $\mathrm{CS}, \mathrm{BaSO}_{4}$ had a positive effect on the thermal performance of PMMA samples by decreasing the maximum curing temperature of PMMA. The $T_{\max }$ for the

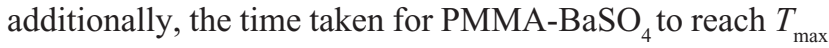
was lower than for the other PMMA-AP samples. This study found no negative cell viability effect on PMMA due to addition of $\mathrm{BaSO}_{4}$ (Figure 6). These results suggest that $\mathrm{BaSO}_{4}$ is also a suitable additive for PMMA based on the mechanical, thermal, and biological benefits achieved. The results of our thermal and cell viability studies are in agreement with those of Ricker et $\mathrm{al}^{7}$ who also found less harmful exothermic reactions during solidification of PMMA and increased osteoblast 

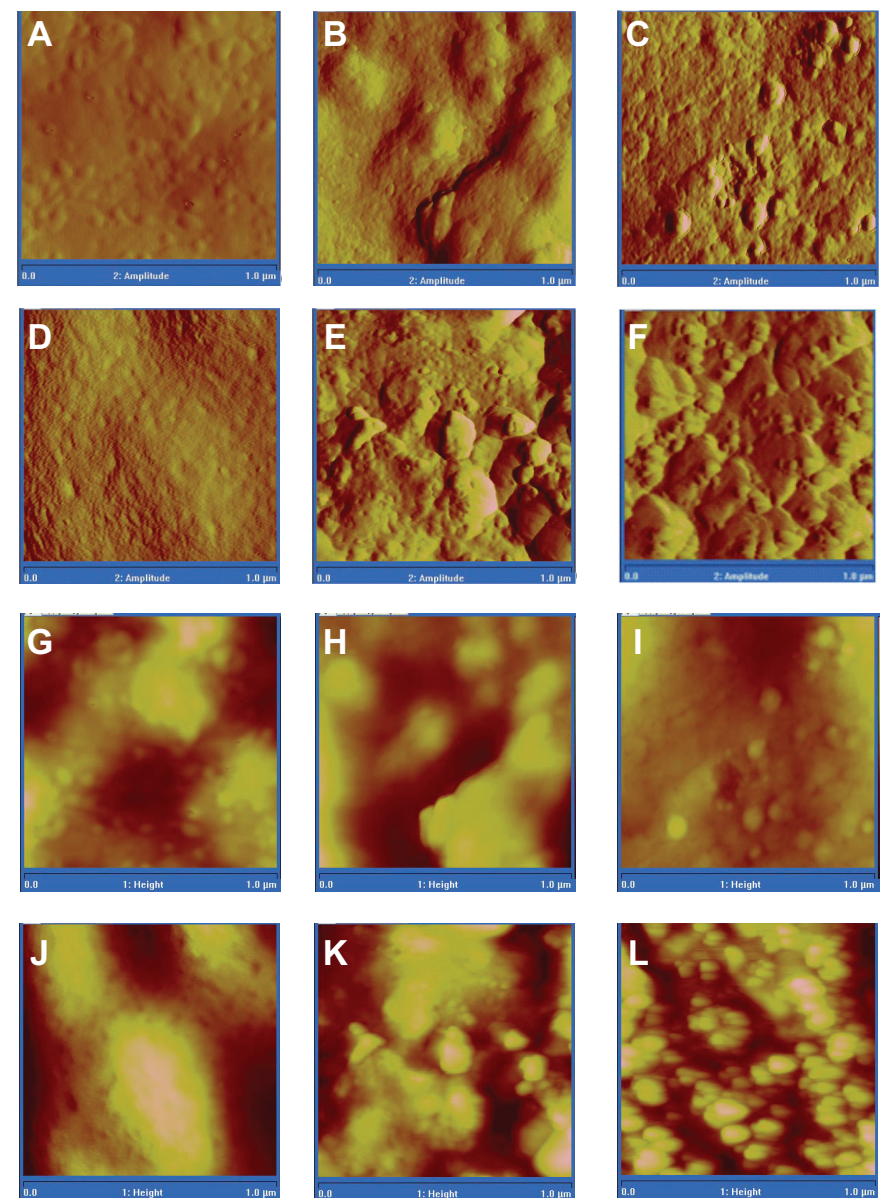

Figure 10 Atomic force micrographs of amplitude $(\mathbf{A}-\mathbf{F})$ and height (G-L) of PMMA, PMMA with MgO, PMMA with HAp, PMMA with CS, PMMA with BaSO, and PMMA with $\mathrm{SiO}_{2}$.

Abbreviations: $\mathrm{CS}$, chitosan; $\mathrm{HAp}$, hydroxyapatite; $\mathrm{MgO}$, magnesium oxide; $\mathrm{PMMA}$, poly(methyl methacrylate); $\mathrm{BaSO}_{4}$, barium sulfate; $\mathrm{SiO}_{2}$, silica.

Table 4 Atomic force microscopy RMS data for different PMMA samples

\begin{tabular}{|c|c|c|c|c|c|c|}
\hline Sample types & RMS parameters & Area I & Area 2 & Area 3 & Average & Standard deviation \\
\hline \multirow[t]{3}{*}{ PMMA } & $\mathrm{R}_{\mathrm{q}}$ & 7.75 & 7.58 & 18.60 & $\mid 1.31$ & 5.16 \\
\hline & $\mathrm{R}_{\mathrm{a}}$ & 5.18 & 6.16 & 15.80 & 9.05 & 4.79 \\
\hline & $\mathrm{R}_{\max }$ & 60.70 & 46.30 & 94.90 & 67.30 & 20.38 \\
\hline \multirow[t]{3}{*}{ PMMA-MgO } & $\mathrm{R}_{\mathrm{q}}$ & 30.80 & 19.40 & 19.70 & 23.30 & 5.30 \\
\hline & $\mathrm{R}_{\mathrm{a}}$ & 24.70 & 13.60 & 14.40 & 17.57 & 5.05 \\
\hline & $\mathrm{R}_{\max }$ & 186.00 & 169.00 & 137.00 & 164.00 & 20.31 \\
\hline \multirow[t]{3}{*}{ PMMA-HAP } & $\mathrm{R}_{\mathrm{q}}$ & 20.60 & 14.90 & 9.75 & 15.08 & 4.43 \\
\hline & $\mathrm{R}_{\mathrm{a}}$ & 16.00 & 12.80 & 7.42 & 12.07 & 3.54 \\
\hline & $\mathrm{R}_{\text {max }}$ & 136.00 & 78.70 & 58.40 & 91.03 & 32.86 \\
\hline \multirow[t]{3}{*}{ PMMA-CS } & $\mathrm{R}_{\mathrm{q}}$ & 6.21 & 8.30 & 16.40 & 10.30 & 4.39 \\
\hline & $\mathrm{R}_{\mathrm{a}}$ & 4.87 & 5.53 & 13.10 & 7.83 & 3.73 \\
\hline & $\mathrm{R}_{\text {max }}$ & 39.00 & 74.10 & 88.60 & 67.23 & 20.82 \\
\hline \multirow[t]{3}{*}{${\mathrm{PMMA}-\mathrm{BaSO}_{4}}_{4}$} & $\mathrm{R}_{\mathrm{q}}$ & 38.00 & 13.70 & 14.70 & 22.13 & 11.23 \\
\hline & $\mathrm{R}_{\mathrm{a}}$ & 29.30 & 9.44 & 12.10 & 16.95 & 8.80 \\
\hline & $\mathrm{R}_{\max }$ & 237.00 & 133.00 & 93.80 & 154.60 & 60.42 \\
\hline \multirow[t]{3}{*}{$\mathrm{PMMA} \mathrm{SiO}_{2}$} & $\mathrm{R}_{\mathrm{q}}$ & 17.00 & 19.10 & 19.10 & 18.40 & 0.99 \\
\hline & $\mathrm{R}_{\mathrm{a}}$ & 13.70 & 15.30 & 15.50 & 14.83 & 0.81 \\
\hline & $R_{\text {max }}$ & 116.00 & 130.00 & 116.00 & 120.67 & 6.60 \\
\hline
\end{tabular}

Abbreviations: $\mathrm{CS}$, chitosan; $\mathrm{HAp}$, hydroxyapatite; $\mathrm{MgO}$, magnesium oxide; $\mathrm{PMMA}$, poly(methyl methacrylate); $\mathrm{BaSO}_{4}$, barium sulfate; $\mathrm{SiO}_{2}$, silica; $\mathrm{RMS}$, root mean square; $R_{q}$, roughness; $R_{a}$, roughness average; $R_{\text {max }}$, maximum roughness depth. 
adhesion on $\mathrm{PMMA}^{-\mathrm{BaSO}_{4}}$ samples compared with PMMA alone. The results of our fracture tests are in agreement with those of Ginebra et a ${ }^{35}$ who also found increased $K_{\mathrm{IC}}$ values for PMMA due to addition of $\mathrm{BaSO}_{4}$.

$\mathrm{SiO}_{2}$ is an inorganic component. We found that $\mathrm{SiO}_{2}$ particles significantly increased the $\sigma_{\mathrm{f}}$ and $K_{\mathrm{IC}}$ values of PMMA (Figure 4). PMMA-SiO ${ }_{2}$ samples had the highest $\sigma_{\mathrm{f}}$ and $K_{\mathrm{IC}}$ values when compared with other PMMA-AP cements. $\mathrm{SiO}_{2}$ had a negative effect on the thermal performance of PMMA samples by increasing the maximum curing temperature of PMMA. The $T_{\max }$ for $\mathrm{PMMA}-\mathrm{SiO}_{2}$ samples was higher than that of the other PMMA-AP cements, except for PMMA-HAp (Figure 5 and Table 3). Also, the time taken for PMMA-SiO $\mathrm{S}_{2}$ to reach $T_{\max }$ was higher than for the other PMMA and PMMA-AP cements. We found no negative cell viability effect on PMMA when $\mathrm{SiO}_{2}$ was included (Figure 6). These results suggest that the detrimental curing temperature effect of addition of $\mathrm{SiO}_{2}$ additives into PMMA bone cement could offset any mechanical and biological benefits achieved. The results of our flexural test and fracture test results are in agreement with those of Hong et $\mathrm{al}^{11}$ and Chan et $\mathrm{al}^{36}$ who reported increased flexural strength and fracture toughness of PMMA-SiO 2 cements when compared with PMMA alone. To our knowledge, no studies have been done to determine the curing properties of PMMA cements incorporating $\mathrm{SiO}_{2}$.

The differences in cell density between the various PMMA samples are due to differences in AP type, dispersion, and topography, and can be seen easily in the SEM images (Figure 9). The differences in cell density between the different PMMA samples are also due to differences in surface roughness, which can be seen easily in the AFM images and data (Figure 10, and Table 4). This observation is in agreement with that of Webster et $\mathrm{al}^{37}$ who also reported that surface roughness enhances osteoblast and osteoclast function, thereby improving orthopedic/dental implant efficacy.

Only one concentration $(10 \%[\mathrm{w} / \mathrm{w}])$ of the selected additives to PMMA cement was evaluated in this study. We also conducted studies using other concentrations ( $2 \%$, $6 \%$, and $10 \%$ ) of PMMA additives and similarly evaluated their mechanical, thermal, and cell function activity. The result of these studies will be published separately. The authors chose to evaluate $10 \%(\mathrm{w} / \mathrm{w})$ of the selected additives in this study because this concentration can produce enhanced surface roughness at the implant-cement interface and bone-cement interface. This allows the surface roughness and interface fracture toughness relationship to be evaluated, which cannot be done using a low concentration of AP $(2 \%$ and $6 \%)$ with PMMA. We also used $10 \%(\mathrm{w} / \mathrm{w})$ of the selected additives to develop and compare the cell viability protocols and data with the published literature for $\mathrm{MgO}$ and $\mathrm{BaSO}_{4} \cdot{ }^{7}$ This study included only one thermal test on PMMA-AP samples because an identical result was found from thermal tests on two control (PMMA) specimens. Therefore, the authors assumed the thermal test data for PMMA-AP samples would vary little. Our study was also limited to only one cell function (adhesion) test. Other cell function tests, including proliferation, alkaline phosphatase, and calcein labeling experiments using different PMMA samples are currently under way.

The novelty of this comparative study is that it attempted to determine the relative influence of microsized $\mathrm{MgO}, \mathrm{HAp}$, $\mathrm{CS}, \mathrm{BaSO}_{4}$, and $\mathrm{SiO}_{2}$ particles on the mechanical, thermal, and biological properties of traditional bone cements used for orthopedic applications. We also developed a novel experimental protocol for curing tests on PMMA-type samples. The novelty of the setup is that the curing experiment can be conducted at constant pressure $(60 \mathrm{kPa})$ and boundary temperature. Additionally, the cured sample blocks for the setup can also be used for mechanical testing. The results of this study can be used to design modified PMMA cements for orthopedic application.

\section{Conclusion}

$\mathrm{CS}$ and $\mathrm{BaSO}_{4}$ are more suitable additives compared with other AP based on the mechanical, thermal, and biological benefits achieved by their inclusion in PMMA. MgO had detrimental effects on the mechanical properties of PMMA cement, $\mathrm{HAp}$ and $\mathrm{SiO}_{2}$ had detrimental effects on the curing properties of PMMA cement, AP had no significant effect on the modulus of PMMA, and AP significantly improved osteoblast adhesion of PMMA.

\section{Acknowledgments}

This research was supported by grant 8P20GM103447 from the US National Institutes of Health and an on-campus faculty grant program from the University of Central Oklahoma Office of Research and Grants. Special thanks are due to Dr Timothy W Teske, Orthopedic Surgery, Enid, OK, USA, for demonstrating the PMMA cement-preparation protocols.

\section{Disclosure}

The authors report no conflicts of interest in this work.

\section{References}

1. The Anderson Orthopaedic Clinic. Total hip replacement. 2009. Available from: http://www.andersonclinic.com/specialties/total-hip-replacementarlington-alexandria-virginia.php. Accessed April 21, 2014.

2. An YH, Draughn RA. Mechanical Testing of Bone and the Bone-Implant Interface. Boca Raton, FL, USA: CRC Press; 2000.

3. Barralet JE, Lilley KJ, Grover LM, Farrar DF, Ansell C, Gbureck U. Cements from nanocrystalline hydroxyapatite. J Mater Sci Mater Med. 2004; $15: 407-411$ 
4. Lewis G. Alternative acrylic bone cement formulations for cemented arthroplasties: present status, key issues, and future prospects. $J$ Biomed Mater Res B Appl Biomater. 2008;84:301-319.

5. Mann KA, Edidin AA, Ordway NR, Manley MT. Fracture toughness of CoCr alloy-PMMA cement interfaces. J Biomed Mater Res. 1997;38: 211-219.

6. Ohashi KL, Romero AC, McGowan PD, Maloney MT. Adhesion and reliablity of interfaces in cemented total joint arthroplasties. J Orthop Res. 1998;16:705-714.

7. Ricker A, Liu-Snyder P, Webster TJ. The influence of nano $\mathrm{MgO}$ and $\mathrm{BaSO}_{4}$ particle size additives on properties of PMMA bone cement. Int J Nanomedicine. 2008;3(1):125-132.

8. Serbetci K, Korkusuz F, Hasirci N. Thermal and mechanical properties of hydroxyapatite impregnated acrylic bone cements. Polym Test. 2004;23:145-155.

9. Tunney MM, Brady AJ, Buchanan F, Newe C, Dunne NJ. Incorporation of chitosan in acrylic bone cement: effect on antibiotic release, bacterial biofilm formation and mechanical properties. Paper presented at the 21st European Conference on Biomaterials, Brighton, UK, September 9-13, 2007.

10. Gillani R, Ercan B, Qiao A, Webster T. Nanofunctionalized zirconia and barium sulfate particles as bone cement additives. Int J Nanomedicine. 2010;5:1-11.

11. Hong RY, Fu HP, Zhang YJ, et al. Surface-modified silica nanoparticles for reinforcement of PMMA. J Appl Polym Sci. 2007;105: 2176-2184.

12. Liu YP, Yu GR, Li K, Yuan F. Is there another possible approach to inhibit wear particles-induced inflammatory osteolysis? Med Hypotheses. 2011;76:280-282

13. Khandaker M, Li Y, Morris T. MgO micro/nano particles for the improvement of cement-bone interface. J Biomech. 2013;46:1035-1039.

14. Khandaker M, Utsaha KC, Morris T. Interfacial fracture toughness of titanium-cement interfaces: effects of fibers and loading angles. Int J Nanomedicine. 2014;9:1689-1697.

15. Zor M, Küçük M, Aksoy S. Residual stress effects on fracture energies of cement-bone and cement-implant interfaces. Biomaterials. 2002;23: 1595-1601.

16. Ramaniraka N, Rakotomanana L, Leyvraz P. The fixation of the cemented femoral component. Effects of stem stiffness, cement thickness and roughness of the cement-bone surface. J Bone Joint Surg Br. 2000;82:297-303.

17. Zelle J, Janssen D, Peeters S, Brouwer C, Verdonschot N. Mixed-mode failure strength of implant-cement interface specimens with varying surface roughness. J Biomech. 2011;44:780-783.

18. Graham J, Ries M, Pruitt L. Effect of bone porosity on the mechanical integrity of the bone-cement interface. J Bone Joint Surg Am. 2003;85A:1901-1908.

19. Funk MJ, Litsky AS. Effect of cement modulus on the shear properties of the bone-cement interface. Biomaterials. 1998;19:1561-1567.

20. Gittens RA, McLachlan T, Olivares-Navarrete R, et al. The effects of combined micron-/submicron-scale surface roughness and nanoscale features on cell proliferation and differentiation. Biomaterials. 2011;32:3395-3403.

21. Im BJ, Lee SW, Oh N, et al. Texture direction of combined microgrooves and submicroscale topographies of titanium substrata influence adhesion, proliferation, and differentiation in human primary cells. Arch Oral Biol. 2012;57:898-905.

International Journal of Nanomedicine

\section{Publish your work in this journal}

The International Journal of Nanomedicine is an international, peerreviewed journal focusing on the application of nanotechnology in diagnostics, therapeutics, and drug delivery systems throughout the biomedical field. This journal is indexed on PubMed Central, MedLine, CAS, SciSearch $®$, Current Contents ${ }^{\circledR} /$ Clinical Medicine,
22. Lee HJ, Kim DN, Park S, Lee Y, Koh WG. Micropatterning of a nanoporous alumina membrane with poly(ethylene glycol) hydrogel to create cellular micropatterns on nanotopographic substrates. Acta Biomater. 2011;7:1281-1289.

23. Martínez E, Engel E, Planell JA, Samitier J. Effects of artificial microand nano-structured surfaces on cell behaviour. Ann Anat. 2009;191: 126-135.

24. McNamara LE, Burchmore R, Riehle MO, et al. The role of microtopography in cellular mechanotransduction. Biomaterials. 2012;33:2835-2847.

25. Prodanov L, te Riet J, Lamers E, et al. The interaction between nanoscale surface features and mechanical loading and its effect on osteoblast-like cells behavior. Biomaterials. 2010;31:7758-7765.

26. Venkatsurya PK, Girase B, Misra RD, Pesacreta TC, Somani MC, Karjalainen LP. The interplay between osteoblast functions and the degree of nanoscale roughness induced by grain boundary grooving of nanograined materials. Mater Sci Eng C Mater Biol Appl. 2012;32: 330-340.

27. Ries MD, Rauscher LA, Hoskins S, Lott D, Richman JA, Lynch F. Intramedullary pressure and pulmonary function during total knee arthroplasty. Clin Orthop Relat Res. 1998;356:154-160.

28. American Society for Testing and Materials International. Annual book of ASTM standards. Section 8. In: D790-03 Standard Test Methods for Flexural Properties of Unreinforced and Reinforced Plastics and Electrical Insulating Materials. West Conshohocken, PA, USA: American Society for Testing and Materials International; 2006.

29. American Society for Testing and Materials International. Annual book of ASTM standards. Section 3. In: E399-90 Metals Test Methods and Analytical Procedures. West Conshohocken, PA, USA: American Society for Testing and Materials International; 2001.

30. Cowin SC. Bone Mechanics Handbook. 2nd ed. Boca Raton, FL, USA: CRC Press; 2001.

31. Lucksanasombool P, Higgs WAJ, Higgs R, Swain MV. Fracture toughness of bovine bone: influence of orientation and storage media. Biomaterials. 2001;22:3127-3132.

32. Dumitriu S. Polymeric Biomaterials. Boca Raton, FL, USA: CRC Press; 2001 .

33. Chu KT, Oshida Y, Hancock EB, Kowolik MJ, Barco T, Zunt SL. Hydroxyapatite/PMMA composites as bone cements. Biomed Mater Eng. 2004;14:87-105.

34. Guibal E, Van Vooren M, Dempsey B, Roussy J. A review of the use of chitosan for the removal of particulate and dissolved contaminants. Sep Sci Technol. 2006;41:2487-2514.

35. Ginebra MP, Albuixech L, Fernández-Barragán E, et al. Mechanical performance of acrylic bone cements containing different radiopacifying agents. Biomaterials. 2002;23:1873-1882.

36. Chan KS, Lee YD, Nicolella DP, Furman BR, Wellinghoff S, Rawls R. Improving fracture toughness of dental nanocomposites by interface engineering and micromechanics. Eng Fract Mech. 2007;74:1857-1871.

37. Webster TJ, Siegel RW, Bizios R. Nanoceramic surface roughness enhances osteoblast and osteoclast functions for improved orthopaedic/ dental implant efficacy. Scr Mater. 2001;44:1639-1642.

ournal Citation Reports/Science Edition, EMBase, Scopus and the Elsevier Bibliographic databases. The manuscript management system is completely online and includes a very quick and fair peer-review system, which is all easy to use. Visit http://www.dovepress.com/ testimonials.php to read real quotes from published authors.

\section{Dovepress}

